\title{
Jihad Salafi: Similar Ideology but Politically Different Strategies in the Southeast Asian Region
}

\section{Mohd Zaini Salleh}

Faculty of Defence Studies \& Management, National Defence University of Malaysia, Sungai Besi Camp, 57000 Kuala Lumpur, Malaysia.

Correspondence Author: Mohd Zaini Salleh, Faculty of Defence Studies \& Management, National Defence University of Malaysia, Sungai Besi Camp, 57000 Kuala Lumpur, Malaysia.

Tel: +60138185616; E-mail: zacksalleh@yahoo.com

Received date: 12 January 2018, Accepted date: 24 June 2018, Online date: 21 July 2018

Copyright: (C) 2018 Mohd Zaini Salleh. This is an open-access article distributed under the terms of the Creative Commons Attribution License, which permits unrestricted use, distribution, and reproduction in any medium, provided the original author and source are credited.

\begin{abstract}
Presently Jihad Salafi (JS) and its movement has become prominent in the eyes of Western and secular perception, interpretation and definition. The latest analysis carried out by RAND Corporation has identified about 60 groups which related to Jihad Salafi's ideology. In a specific sense, Western states are mainly concerned with ideology, international networking, structure and capabilities, growing numbers of JS groups, leadership pattern, and support elements which could threaten their states, coalition, allies, and other interests' mainly in international economic activities. A deep understanding of JS teaching is still ambiguous among Western policy makers, their people and their political systems. Misunderstanding of the word 'jihad' has jeopardised the true meaning of Islam and the content of holy Qur'an. Furthermore, JS in a true sense has brought different political objectives interpretation and perception among international terrorist groups and separatist movements particularly in the Southeast Asian region. In fact, some other separatist movement groups in the Southeast Asian region are not categorized into terrorist groups due to their differences of political objective to liberate their motherland from central government i.e. Southern Thailand, Southern Philippines and Aceh conflicts. The government of Malaysia and Indonesia has had experience by putting a strong effort to deny a negative perception about JS and Islam religion which always been accused sponsoring and encouraging extremism and terrorism activities.
\end{abstract}

Key words: Jihad; Ideology; Al-Salaf; Tabi'in; Tabi' Al-Tabi'in; Imam; Fardu Ain; Fardu Kifayah; Wahabi; Sunni; Shiite; Separatist; Political Aim

\section{INTRODUCTION}

In contemporary context, Jihad Salafi (JS) is commonly perceived as synonymous with Islamic extremist movements such as the Al-Qaeda and its operational networks in the Southeast Asian region, such as the Jemaah Islamiyah (JI), Abu Sayyaf Group (ASG), and other extremist religious groups. Most of the Western countries associate these organisations with international terrorism activities, with JS as the main doctrine or ideology guiding them. Jenkins postulates that there were 32 jihadist terrorist plots uncovered since September 11, 2001. Out of these only ten had what could be described as an operational plan. Six of these plots were put under close-monitoring by intelligence agencies [1]. According to RAND report published in 2014, there are about 60 JS groups around the world [1]. All of them are from Islamic states or states with Muslim majority which are concentrated in the Middle East and North Africa. There are also groups that come from other Muslim majority and mixed Muslim non-Muslim states in Africa and Southeast Asia. JS groups were noted to have grown after the $9 / 11$ incident. This report has postulated a negative perception about Islam, Islamic states, the Muslim ummah and as a whole, Islam as a religion.

Western and secular perception, interpretation and definition of JS attempt to relate not only with the above mentioned organisations, but also with other separatist groups in the region such as Moro National Liberation Front (MNLF) in Mindanao, Philippines, Barisan Revolusi Nasional (BRN) and Pattani United Liberation Organisation (PULO) in Southern Thailand, Thailand, and Gerakan Acheh Merdeka (GAM) in Aceh, Indonesia. Consequently, these organisations have been blamed for the conduct of terrorist activities and operations in their respective sub-regions. These organisations are also suspected of having strong relations with other international terrorism groups such as JI and Al-Qaeda. Arguably this situation exists as a result of simplistic interpretation of Jihad Salafi which lacks depth and careful examination of the doctrine and its relationship with the motivation of war and conflict.

Research Method:

This paper is solely applying a qualitative research approach by examining and comparing facts and findings based on secondary data acquired from the respective information and studies conducted by individuals, organizations such as RAND corporation and etc. A simple comparative approach postulated into this paper in order to differentiate sum ideological goals between terrorist and separatist movements, particularly in the area of Southeast Asian region dealing with jihad salafi's ideology. Somehow or rather a deep empirical data collection is not acquired in this paper due to time constraints. It is a basic concept paper to fulfil a standard presentation requirement, and it would be prolonged with a proper research afterward.

Conceptual Framework:

This paper is based on realism thinking by doing a simple comparative study dealing with the issues of Jihad Salafi (JS) ideology dealing with regional and international security issues. It is not intending to discuss and highlight the practice of this particular ideology in deep but rather to postulate the significance of the JS ideology being practiced by differences groups which could be either international terrorist groups or separatist groups to achieve their political aims in the Southeast Asian region.

Current international security phenomenon which could give impacts of threats toward nations around the world is not only confined to traditional spectrums i.e. political/ideology and military domains, but wider inclusive non-traditional spectrums i.e. economic, social and environment domains in the form of multi- 
dimensional security complex. Initially religion element is part of social domain but lately this element becomes more imminent by influencing political or ideology domain of state actors or non-state actors. The most fears factor among western world is non-state actor which could able to spread international link and network within the ideology or principle of JS.

\section{Definition and Ideology:}

The words Salafi or Wahabi refers to two different terminologies, but in reality, are a similar religious teaching or ideology [2]. The teaching approach is radical both in the conceptual as well asin practical spectrums. Salafi comes from the word Al-Salaf, which means referring to the glorious periods of early Islam particularly during the reign of the companions of the Prophet Muhammad SAW. The terms are also known as tabi'in and Tabi' al-Tabi'in, as knowledge acquired from imam who inherits the knowledge and teaching from the early generations [2]. Later, the term Salaf brings the definition of pioneers or forebears - to be a perfect role-model to be followed. The term Salafi means those who follow the role-model of the early generations of Tabi' in, Tabi' al-Tabi'in and imam [2]. Subsequently, this teaching was spread by Wahabi teachings initiated by Muhammad bin Abdul Wahab (1702-1787) derived from the main stream of Ahlus Sunnah Wal Jamaah [2]. The word Jihad based on moderate connotation carries the meaning "struggle" or "resisting" or "putting maximum effort". A person engaged in a jihad is called a mujahid, the plural of which is mujahideen. The word jihad appears frequently in the Quran, often in the idiomatic expression "striving in the way of God (al-jihad fi sabil Allah). But the definition is not referring to the Jihad Salafi alone since jihad in Islam is not only restricted to war and conflict per se. It also covers various aspects of Muslim life i.e. political, military, economic, and social. It also covers diverse range of religious issues that range from Fardu Ain to Fardu Kifayah - as long as the ultimate goal is to achieve God's alleviation. In short, the Salaf faith and its elements are also part of Sunni teaching methodology from Khulafa Ar-Rasyidin's glorious period until today. Radical and extremist approaches brought about and perpetrated by the JS groups such as Al-Qaeda, JI and ASG have created a negative image of Islam. Islam is presently labeled as a religion which encourages extremism and terrorism.

In order to counter this negative perspective on Islam, the position of JS and other extreme jihadist groups should be properly clarified. Besides Salafi Wahabi, there are also several other extreme jihadist groups operating particularly in the Middle East such as Salafi Yamani and Salafi Takfiri. In a simple understanding of Islamic fundamental teaching, JS is not another branch of Islamic belief or sect like Sunni or Shiite. Sunni alone is divided into four main sects i.e. Hanafi, Maliki, Hambali and Syafie; whereas Shiite is divided into at least twelve sub-sects. Both beliefs of the main sects cover every aspect of the way of life; ranging from individual matters (fardu ain) up to society and statecraft domains (fardu kifayah). These radical and extreme groups could be considered as factions from the mainstream Sunnis by forming up their ideology and teaching approaches. The most extreme situation arises when these JS groups decided to confront other Muslims which they deem to have strayed from the original Islamic doctrine. Openly they resort to armed struggle to establish their own 'Islamic States' as what is happening in Iraq, Syria, Nigeria, and in the case of Philippines, the declaration by the Abu Sayyaf group the Islamic State in the Southern Philippines.

According to Zulkarnain Haron \& Nordin Hussin [2], Salafi or Wahabi is a religious ideology which emerged as a reaction to a social phenomenon rather than a change in religious doctrine [2]. By coincidence, most of the radical fundamental Islamic movement came from the Sunni sect. It began with the emergence of new interpretations during the era of Western colonialisation and expansion, the influence of the changes brought about by the end of Ottoman rule in Arab states after World War I, and the impact of World War II. Some of these new ideological concepts spread to the Southeast Asian region during these periods. The level of extremism brought about by these new radical concepts depended very closely on the threat perceptions the communities were facing against Western concepts such as modernity, secularity, and the new political ideal of nation-states [3]. Since the threats mostly came from the Western thoughts and civilizations in changing societies, the response foci were either to deter, to curb, to channelize, to absorb or to confront due to impacts to the internal societies or states' political system.

Western states are more concerned with ideology, international networking, structure and capabilities, growing numbers of JS groups, leadership pattern, and support elements which could threaten their states, coalition, allies, and other interests' mainly in international economic activities. RAND research has given the definition and identification of JS which related closely to militant Sunni Islamism:

"a group is defined as Salafi-jihadist based on two criteria. First, the group emphasizes the importance of returning to a "pure" Islam, that of the Salaf, the pious ancestors. Second, the group believes that violent jihad is fard 'ayn (a personal religious duty).Fard 'ayn includes tasks every Muslim is required to perform, such as zakat (almsgiving), hajj (the pilgrimage to Mecca), salat (daily prayers), sawm (fasting during Ramada), and the shahada (accepting Muhammad as God's messenger). Jihad is not one of these five pillars. It is, instead, a collective duty (fard kifaya) under certain circumstances. A fard kifaya is an act that is obligatory for the Muslim community collectively. But if it is sufficiently carried out by some members of the Muslim community, then other Muslims do not have to perform it. An example is the prayer performed at a Muslim burial. Still, most Salafi jihadists consider violent jihad an individual duty, or fard 'ayn" [1].

A deep understanding of JS teaching is still ambiguous among Western policy makers, their people and their political systems. Misunderstanding of the word 'jihad' has jeopardized the true meaning of Islam and the content of holy Qur'an. It is a fundamental need for every Muslim by having jihad spirit in order for them to be more pragmatic, progressive and move forward in every aspect of life without ignoring Allah's alleviation. Islam political system also allows elements of political systems to be absorbed into Islamic framework since it is not against the fundamental teaching and faith (akidah) of Islam. Prophet Muhammad himself once encouraged his followers to explore new knowledge from countries as far as China and other countries. But in the Western world, jihad and the religion of Islam are viewed negatively and tend to be associated with violence, terrorism, war and conflict.

\section{Political Aims And Motivations In Southeast Asian Region:}

International and Regional Terrorism Organisations:

Generally speaking the international terrorism organisations in Southeast Asian region are related to Al-Qaeda's network. JI as a major terrorist group in this region is known to have worked closely with Al-Qaeda by attempting to take advantages of internal conflict in various Southeast Asian countries. This organisation also has close ties with the Abu Sayaf Group (ASG) in Southern Philippines (Mindanao). Originally JI was established at Kg Serting, Kuala Pilah, Negeri Sembilan, Malaysia in 1993, but it later flourished tremendously in Indonesia under the leadership of Abdullah Sungkar and Abu Bakar Bashir. Both of them fled to Malaysia in 1985 to escape imprisonment by Indonesian government under Suharto regime. The idea of establishment of JI rooted in Darul Islam (DI) movement in Indonesia which closely monitored by Angkatan Bersenjata Republik Indonesia (ABRI) [2]. Both of them also had experience during anti-Soviet jihad war in Afghanistan, and managed to establish contact and networking with Al-Qaeda leadership and the Moro Islamic Liberation Front (MILF), a faction from the main MNLF, including its radical wing ASG. As clarified by Daljit Singh [4], the ultimate goal of JI was:

"to work towards a pan-Southeast Asian caliphate embracing Indonesia, Malaysia, Singapore, southern Philippines and southern Thailand. JI received funds and training support from Al-Qaeda. The latter also helped JI, through its links with the MILF, to establish training facilities for JI in MILF areas of Mindanao"

The main reason why Al-Qaeda and JI decided to choose the respective countries and sub-regions is because they have a large number of Muslim population. Indonesia is inhabited by a majority Muslim population and has the largest number of Muslims in the world, whereas other areas like Southern Philippines and Southern Thailand were chosen due to other factors such as lack of governance by central government and prevalence of poverty. These conditions provided them with space, time and man-power to establish their operational bases. Among the major attacks by JI took place during the period around 2000-02, which include the first Bali bombing of October 2002 [4]. The 2000 Sauk incident in Perak, Malaysia was also strongly believed to have been planned by JI through its subordinate militant organisation Al-Maunah. Their struggle and major plots mainly targeted the US, her allies and other Western interests in the Southeast Asian region such as; embassies and military establishments (representing political and military domain), and hotels, tourism centers and factories (representing socioeconomic domain). 


\section{Separatist Movements:}

According to Daljit Singh, the differences that emerged between various JS groups are over issues of strategy and tactics, not over ideology [4]. It is especially true when seen in the context of the additional characteristics, ultimate goals and levels of radicalism or extremism of respective militant organizations. Separatist movements such as BRN and PULO in Southern Thailand, GAM in Aceh, Indonesia and Moro National Liberation Front (MNLF) in Southern Philippines can be considered as separatist movement groups. These separatist groups are also adopting the element of JS teaching and Wahabism as one of motivation strength, but the ultimate goal is to liberate their motherland from central government due to long historical incident and protracted struggle. The JI have attempted to influence these separatist groups on numerous occasions but failed because of the differences in the ultimate political goals.

Latest development in the above-mentioned separatist groups are not listed in RAND report of 60 JS radical groups around the world. There are several reasons for this exception:

1. Numerous research has been carried out by research centers, institutions, scholars and individuals from western countries proved that historical background and the root-cause of conflicts in the regions of Southern Thailand, Southern Philippines and Aceh have no connection with the international terrorism organisations and their networks.

2. A series of international forums, seminar, conferences, dialogues and negotiations gave a clear picture about the long standing conflict taking place in this region.

3. These separatist groups enjoy international support particularly in the area of humanitarian assistance, from European countries particularly Scandinavian countries.

On the other hand, MILF is still in the list of 60, strongly suspected of having close networking with ASG. The International Monitoring Team (IMT) sponsored by the Organisation of Islamic Cooperation (OIC) is putting a strong effort to engage MILF in the mainstream dialogue and negotiation by identifying their movement's goals. But some statements from local informants in Sabah indicated that there are possibilities that militant members of ASG could join MILF, or vice versa. This might possibly be the reason the organisation still being considered as a terrorist group. Their modus operandi depends on the situation an include kidnapping, assassinations, sabotages etc. Their targets are mainly Western interests and citizens.

Conclusion:

In short, Jihad Salafi is not an extremist ideology. It is part of the fundamental teachings of the Islamic way of life in the Sunni sect. Extremism and radicalism are also not ideologies of Jihad Salafi, but a different interpretation and execution strategy to comprehend the ultimate political goals by Islamic groups. Varying ethnic compositions within the countries may also prevent extremism and radicalism which lead to international terrorism. Due to the challenges and threats of international terrorism movements in early 2000s, the governments of Indonesia and Malaysia have embarked on intensive programs to guide the Muslim community to adhere into the mainstream teachings of Sunni Islam. Through its religious institutions Nahdatul Ulama (NU) and Muhammadiyah, Indonesia has introduced Islam Liberal (Liberal Islam) and Islam Progresif (Progressive Islam) thoughts. Under the premiership of Abdullah Badawi, Malaysians were encouraged to subscribe to the thoughts of Islam Hadhari (Civilisational Islam). All these three types of thoughts shared the same philosophy in creating liberal, moderate and puritanic Islamic way of life without neglecting the spirit of jihad, in a peaceful non-violent manner.

\section{REFERENCES}

[1] Jones, S.G., 2014. A Persistent Threat, The Evolution of al Qa'ida and Other Salafi Jihadists, Rand Report, RAND National Defense Research Institute: ix, 2: 63-65.

[2] Zulkarnain Haron and Nordin Hussin: 'Islam di Malaysia: Penilaian semula fahaman salafi jihadi dan interpretasi jihad oleh Al Jama'ah Al Islamiyah', Malaysian Journal of Society and Space, 9 Issue 1, Kuala Lumpur, pp: 127-129.

[3] Kamaruzzaman Bustaman-Ahmad \& Jory, P., 2013. Islamic Thought in Southeast Asia, New Interpretations and Movements, University of Malaya Press, Kuala Lumpur: xiv.

[4] Daljit Singh, 2009. Terrorism in South and Southeast Asia in the Coming Decade, Trends in Terrorism in Southeast Asia, ISEAS, Singapore, pp: 84-85. 